\title{
A Comparative Discourse Analysis of Western and Local (Nigerian) Media Depictions of the Presidential Pardon of Diepreye Alamieyeseigha
}

\section{Awobamise Ayodeji Olalekan, Girne American University, North Cyprus}

\begin{abstract}
Nigeria has been at the forefront in corruption scandals in the past and has consistently ranked high on the list of most corrupt nations in the world. The Nigerian government since president Obasanjo's regime from 1999 to 2007 tried different ways to stamp out corruption; most notable was the formation of the Economic and Financial Crimes Commission (EFCC) in 2003. The EFCC led by Nuhu Ribadu, successfully indicted a lot of politicians and other fraudsters in the country, but due to judicial corruption or ineptitude, most of the indicted politicians were let go on some technicality or given suspended sentences. One of such politician indicted was Former Governor of Bayelsa State, Diepreye Alamieyeseigha. He was recently granted a presidential pardon by the President Goodluck Jonathan. This pardon has been widely publicized by both local and international press. This work is simply an analysis of both western and local media depictions of this pardon when they reported the news. The writer shall make use of Van Dijk's social Ideological Discourse Theory and Ideological Square also by van Dijk. It is the hope of the writer that this work shall further enlighten scholars on how through careful analysis using the write tools, one can begin to understand the underlining meanings in words and get what the writer really means to portray or pass along.
\end{abstract}

Keywords: Discourse Analysis, ideological square, semantics, macrostructures, macroproposition and superstructure 


\section{Introduction}

Over the years Nigeria has been embroiled in steep corruption and the leaders have constantly been in the news for bending the laws to suit their personal agendas. This has been closely monitored and reported by the media, both local and international. Due to this coverage, it is only safe to assume that certain stereotypes and opinions might have been developed about Nigeria as a country and Nigerians as a people. These stereotypes might have developed into ideologies that are influencing the reporting of news and events concerning Nigeria. This work aims to find out the ideological differences between local media and western media's depiction of the presidential pardon of Alamieyesigha. The comparison shall be conducted against the backdrop of Van Djiks ideological Square and theory of Semantic macrostructures. By carrying out a comparative analysis of news reports, it would give us an understanding of the ideological make-up of the different news. Fowler (1991) explained how powerful the press is when he said that "both the tabloid and quality press are instrumental in the ideological manipulation of their readers"

\section{Aims and Objectives}

The aim of this research is to through critical discourse analysis of news articles concerning the presidential pardon from western and local sources try to understand the current impression of Nigeria's fight against corruption as against what we think locally, assuming the press represents societal values and perception.

The article analyses news reports on the presidential pardon given Diepreye Alamieyeseigha, by President Goodluck Jonathan as covered by 2 western news sources and two Nigerian papers.

The objective of this article is to examine:

1. The difference and the similarities in the Macropropositions and Globalstructures

2. The difference and similarities in local meanings, lexical style and rhetoric 


\section{Data Criteria}

The source of the news articles were selected based on careful considerations. The Vanguard and Punch newspapers were chosen because they are widely circulated in Nigeria and also have strong online presence, these papers represent the local news sources on the issue of Diepreye Alamieyeseigha's pardon by the Nigerian President, while the New York Times and the BBC world news (online) would represent the western perception of the news.

Below is a list of the sources and their headlines:

1. Vanguard Newspaper (online): Alamieyeseigha has demonstrated enough soberness Presidency

2. BBC news (online): Nigeria pardons ex-governor who stole millions

3. New York Times (Online): U.S. Embassy Criticizes Pardons in Nigeria Corruption Cases

4. The Punch Newspaper (Online): Jonathan's 2015 plan behind ex-gov's pardon Investigation

The major criteria in selecting the above named news sources is simply their reputation. The Punch and Vanguard both represent the most widely read newspaper online in Nigeria and as such they are very influential source of information and news to Nigerians. The New York Times and the $\mathrm{BBC}$ are also a major source of international news. Also they all address the same issue and around the same time, which gives us an opportunity to get different perspectives from completely different locations and probably ideology.

Another reason for choosing to use 4 different newspapers ( 2 western based and 2 local) is that it would present an opportunity to empirically study the differences in writing and orientation. As Phillips and Jorgensen (2002) explain it, the simplest way of building an impression of the nature of text is to compare it with other text.

\section{Scope of Study}

This work analyses Western (BBC and New York Times) and Local (Punch and Vanguard Newspapers) reports covering the presidential pardon of Diepreye Alamieyeseigha. This work shall be limited to using discourse analysis to analyse the text and shall not include detailed quantitative or qualitative analysis. 


\section{Theoretical Framework}

This article shall draw upon two theories of news discourse, namely:

1. Theory of ideological square by Van Dijk

2. Theory of Semantic Macrostructures by Van Dijk

To carry out a proper analysis of news text, it is usually better to use a combination of theories or methods that would best answer the underlying questions of the research. These theories are applied to examine the cultural, social, political and ideological factors if any that may have affected the news coverage of the presidential pardon of Alamieyeseigha.

The ideological Square theory by Van Dijk is concerned with the question of ideology. Van Dijk notes that opinions maybe expresses in many complex ways in text. The ideological square as explained by Dijk is intended to highlight key functional moves in developing an ideological strategy (Philo, 2007).

He went on to explain that an ideological account would.

1. Emphasise our good properties/actions

2. Emphasise their bad properties or actions

3. Mitigate our bad properties/actions

4. Mitigate their good properties/actions

The theory of ideology has certain levels of description of the semantic components in a text and there are:

1. Explicitness Versus Implicitness

2. Generality Versus Specificity

3. Negativity Versus Positivity

4. Directness Versus Indirectness

5. Direct questioning Versus Statement

For an article to be considered linked to an ideology it must fall into one of this categories. It implies that a news text must be in our favour, interest or should impact positively on our image while doing the opposite to our opponents or enemies.

In the Theory of Semantic Macroproposition, Van Dijk identifies 3 major levels of news discourse; Semantic Macropropositions, global superstructure (news schema) and Local meaning (microsemantics). This work shall identify these 3 levels in the chosen news articles and base the analysis on them. 
The Semantic Macroproposition or macrostructures is simply the global meaning of the text. In trying to get the semantic Macroproposition, we look at the news report as a whole, by identifying the Macroproposition, we should have a good idea of what the whole text is about i.e. the theme of the article. Van Dijk in his article on the pragmatic Macro-structures in Discourse and Cognition further explained that "semantic macro-structures make explicit the important intuitive notion of topic of discourse: they specify what a discourse, as a whole, is about, in a non-trivial way, i.e. not by a simple enumeration of the meanings of its respective sentences". Macrostructures also contribute to local coherence at the micro-level of connections between propositions in composite sentences and successive sentences (Van Dijk, 1988). The semantic can be divided into two, the primary Macropropisiton contains the main message, the secondary one reveals the ideology of the writer, which can be identified through analysing the choice of words and also the background of the writer or the policies of the media outlet (Ghayda, 2011). In a nutshell, the macroproposition explains what is important, relevant or prominent in the discourse as a while (van Dijk, 1988), it gives meaning to the message and makes it easier to understand the news.

The global superstructure or news schemata identify the structure of the news, which can be used as a bench mark to identify any flaws in the article. For instance if it is agreed that a news should have an Heading, Lead, Body, background, conclusion and evaluation (the schemata), and it is discovered that a news article is missing part of this sections, then such an article can be said to be incomplete. Van Dijk explained that Superstructures are organising principles of Discourse and they character hierarchy thereby defining the content of the text. In a nutshell we try to identify the structure of the news text and see if there is any logical sequence based on our understanding of what to expect from a news article.

The Local meaning of a text characterizes its microstructure, consisting of the meanings, word groups, clauses, sentences and sentence connections. The local meaning collectively forms the macroproposition and should give a clearer understanding of the heading or main topic (Van Dijk, 1988). 


\section{Assumption}

The basic assumption of this research is that newspaper's government interests, as well as the ideological and cultural makeup of the media houses exert important impacts on the construction of coverage of the presidential pardon.

\section{Analysis Methodology}

This work shall make use of Discourse Analysis as described by Van Djik in his Theory of Semantic Macrostructures.

The analysis of each newspaper article shall begin with the headline analysis, which would involve examining the headline to find out the main theme, the major actors and structure. It is at this point that we identify the semantic macroproposition.

Once the headline analysis has been completed we move on to examine the body of the news report to determine participants, structure and if available secondary themes. The local meaning analysis then attempted which involves examining lexical style and rhetorical dimensions present in the news reports. Once these have been successfully completed it is then easy to identify the ideological influences that were in play while writing the article.

In a nutshell this comparative analysis shall be analysed by identifying the semantic macropropositions, Global Structures and local meanings in the news articles.

\section{Analysis 1: BBC News (online)}

Headline: Nigeria Pardons Goodluck Jonathan ally, Alamieyeseigha

Date of Publication: 13 March, 2013

\section{Semantic Macroproposition}

A news headline usually is a summary of the news report or at least should give a reader a general idea of where the news is headed. The headline in combination with the lead paragraph should be able to answer some of the important questions in news writing which are the what, who, where and why. This headline answers the 'what' Nigeria grants Alamieyeseigha pardon, 'who' - Alamieyeseigha, 'where'- Nigeria, 'why'- Because Alamieyeseigha is an ally of President Goodluck Jonathan. This news article's headline is clearly implying some sort of favouritism in play here; as it makes it immediately known that Alamieyesegha is an ally of the president. Though it might be true that Alamieyeseigha is a 
political ally and benefactor to Nigeria's current president (Goodluck Jonathan), it is however implicitly stating that the reason for the pardon is because the ex-convict is a friend to the president. The choice of structuring the headline that way and using the word Ally, clearly lets the readers know that $\mathrm{BBC}$ (and probably the Western world) does not support the decision. The headline also introduces the major players or characters in the news; Alamieyeseigha, Goodluck Jonathan and Nigeria.

In view of the above points, I believe that the headline is not just a news summary, but also an editorial commentary or evaluation. The writer clearly considers the pardon unreasonable and based solely on the fact that the ex-convict is a friend to the president and not on merit.

\section{Local Meaning}

In understanding and analysing a news text, it is pertinent to look at the structure, the writing style, linguistic and rhetorical elements of the text to get a broader understanding of the message being passed across. The participants in this news item are; President Goodluck Jonathan, Alamieyeseigha, Mr. Okupe, Nuhu Ribadu and Bamidele Aturu. These participants help lend credence, legitimacy and authenticity to the news. It gives the reader an impression that the news is authoritative enough as it is backed up by opinions of relevant authorities. From the article we can begin to identify two groups, the in-group represented by those against the pardon (good guys) and the out-group represented by those in support of the pardon (bad guys). The writer is clearly trying to depict the presidential pardon as unreasonable and impress on the minds of the readers that the decision is a setback in the fight against corruption. BBC clearly supports the views of those against the pardon as can be deduced from the news. They have a sub-heading, "Irresponsible decision" and in the body have a statement from The Senior Special Assistant to the President on Public Affairs, Doyin Okupe which supports the pardon. Okupe stated that, "He was tried, jailed and dispossessed of his property. He has been remorseful, there's no law against the granting of pardons to any criminal." This is the only statement from the out-group and even that had been earlier implied to be shady by the use of the parenthesis when writing the "remorseful". The use of parenthesis is clearly casting doubt on whether or not Alamieyeseigha was truly remorseful. Other comments in the article were clearly against the pardon as can be seen by statements from Bamidele Aturu, a prominent Nigerian Lawyer and activist, and Nuhu Ribadu former chairman of the Economic and Financial Crimes Commission (EFCC) in Nigeria. 
It is clear from the number of comments that the news is skewed in favour of the in-group. It is not objective as it does not give equal opportunity for both sides to state their arguments, though it pretends to be by using one comment. This is however not enough as the readers would be made to believe the in-group have a superior argument based simply on the number of comments from them as against only one comment from the out-group. The only comment on support of the pardon

The writer makes use of dramatic and sensational language, this can be seen right from the headline and is also visible in the body of the news text - the writer chooses to use words that are sure to pique the interest of the reader such as "Jonathan's Ally" in the headline, "key Ally" in the first paragraph using parenthesis in "remorseful" in the second paragraph.

The choice creating a sub-heading titled "irresponsible Decision", clearly points to the fact that the news writer does not want his message lost in translation, and the message is the decision was unreasonable and irresponsible. This can be seen from the choice of having only one comment from the supporter of the pardon and two comments from those against it. The only comment in support is from a government official, which one can assume is the official statement and as such cannot be viewed as public opinion. The BBC analyst Fidelis Mbah further rubs the point in by saying, "Mr Alamieyeseigha is now free to run for political office again, and could bolster Mr Jonathan's Mr Alamieyeseigha is now free to run for political office again, and could bolster Mr Jonathan's chances of winning another term in elections due in 2015". All these points to the fact or the assumption that the pardon granted Alamieyeseigha was a political move to improve President Goodluck Jonathan's 2015 chances. The article also makes a point of giving a brief history of Nigeria as regards Alamieyeseigha, all of which paints a bleak picture. The background story offered clearly gives us the reasons why he SHOULD NOT be pardoned.

The article also made some assumptions which cannot be said to be objective, for instance the writer claims that Alamieyeseigha is expected to rally support for Goodluck Jonathan in Bayelsa also stating that support for Jonathan has fallen in the region. These statements are just assumptions as the writer did not give any evidence that the support for Jonathan in Bayelsa has fallen, and neither has it been implied by any of the parties that Alamieyeseigha would be campaigning for Jonathan. These statements further prove that the writer is biased 
against the decision to pardon Alamieyeseigha. Also the writer tries to rub it in that the exconvict is close to the president. This can be noticed right from the headline with the choice of the word "Ally" which was also used again in the first paragraph. He also referred to the president as the deputy to Alamiayesiegha when the later was governor of Bayelsa. This further impresses on the mind of the reader that something shady had gone down in the granting of this pardon.

\section{Global Superstructure}

The news report is based on the presidential pardon granted Alamieyesiegha in Nigeria. It follows a traditional news format with a heading, lead, body and conclusion. It however deviates a little by having a sub-heading in the body, which divides the story into two, the main news and comments on the issue. The news does not completely answer the $5 \mathrm{Ws}$ and $\mathrm{H}$ of news writing, here is a list of what it does attempt to answer:

What- Presidential Pardon of Ex-governor and ex-convict Diepreye Alamieyesiegha.

Who - Diepreye Alamieyesiegha

Why - Because he is an ally of current president (based on the analysis of the article)

Where - Nigeria

The article did not however state the "When". There is no way for the reader to know when the pardon was granted based on the information provided in the news. Also "How" the pardon was granted, the steps followed in granting the pardon was not stated. It is possible that if these missing elements were present, then readers' perception might be different.

\section{Analysis 2: New York Times (Online)}

Headline: U.S. Embassy Criticizes Pardons in Nigerian Corruption Cases

Writer: ADAM NOSSITER

Publication Date: 15 March, 2013

\section{Semantic Macroproposition}

This headline gives a brief summary of what the news entails. It also immediately establishes to major players, US as the in-group and Nigeria has the out-group. The headline answers the 'what' US criticizes Nigeria, 'who' - Nigeria, 'where'- Nigeria, 'why'- pardon of corrupt people. The headline though factual, can also be interpreted as meaning the US is not in support of it, which automatically in the mind of the readers, means the world is not in support of it. 
The headline also introduces the major players or characters in the news; Nigeria and US Embassy. The headline is misleading, as it gives the impression that they US criticized several corruption cases, whereas from the body of the article it is clear that their major grudge is against the pardon of Alamieyesigha in particular, as the body of the article was almost completely about his pardon. From the headline it is clear that the New York Times is not in support of the pardon, as the writer chooses to use the US embassy's critic as the main topic rather than a more conventional title like; "Nigeria Pardons some Ex-convicts". This would have still passed across the message, without necessarily influencing readers' perception. But by writing the US embassy criticizes, people immediately conclude that the pardon was wrong, since most people view US as the perfect example of a working democracy and as such they no best.

\section{Local Meaning}

The participants in this news item are; President Goodluck Jonathan, Alamieyeseigha, Mr. Okupe, Nuhu Ribadu and Unites States Embassy. These participants help lend credence, legitimacy and authenticity to the news. It gives the reader an impression that the news is authoritative enough as it is backed up by opinions of relevant authorities. The article makes use of the delayed identification lead, which withholds a significant piece of the information; in this case, it withholds the name of the main topic of discussion which is Alamieyeseigha. This does nothing other than stimulate the reader's interest, as people would be eager as to who the statement/lead is addressing or referring to.

The article is clearly about the presidential pardon of Alamieyeseigha, even though the headline would have us believe otherwise. From the first paragraph, it is clear the writer considers Nigeria a very corrupt and lawless country. The article makes it clear that the view or sentiment is not one held by the US alone but even Nigerians are strongly not in support of the pardons. This is seen from the first and second paragraph and throughout the article;

"Convictions for corruption by top officials in Nigeria are so rare that they are treated as national milestones. So when the government rolled back one of the most prominent of them this week, the shock was commensurate. On Friday, the United States fuelled a growing fracas over the pardoning of Diepreye Alamieyeseigha 
From the statement above it is clear that the writer wants us to understand or believe that his Nigerians and the international community are disappointed at the government's decision to pardon Alamieyeseigha.

Like the BBC's news article on the same issue, the writer, Adam Nosssiter has also taken time not to give a balanced view on the issue. They are a total of about six (6) comments and only one is from the government of Nigeria's point of view, while the remaining 5 are from civil society groups and Nuhu Ribadu which are clearly against the pardon. The author is giving the readers the impression that nobody was in support of the pardon, whereas there are definitely a lot of people from Alamieyeseigha's town and the People's Democratic Party (PDP) that are in support of it. This again is playing on the psychology of the readers to impress on their minds that the action was condemned by ALL Nigerians except those in government, which might not necessarily be the case. It is clear from the number of comments that the news is skewed in favour of those against the pardon. It is not objective as it does not give equal opportunity for both sides to present their arguments. Also has regards to Nigeria's public image in terms of corruption, it is clear that the writer see Nigeria as a country where anything goes and corruption is allowed and celebrated. This can be seen in statements like, "Convictions for corruption by top officials in Nigeria are so rare that they are treated as national milestones", "According to the country's few anticorruption campaigners....", "But then, almost as surprisingly, he was pursued by the Nigerian authorities, specifically Mr. Ribadu's commission...". These statements reflect the writer's personal opinion about Nigeria which might have been birthed by the stereotypical depictions of Nigeria and Africans generally in the news. It is clear that the writer views Nigeria as a very corrupt country, and considers it a 'big deal' that Alamieyeseigha was prosecuted in Nigeria at all. Also the writer's opinion is reflected in this statement, "But his political rehabilitation, at least in ruling party circles, was swift. A mere 10 months after his conviction..." the choice of the adjective "mere" in this sentence implies the writer views 10 months is too short, which again not objective as the sentence could have done without the word at all in the first place. The article also intermittently gives a history of corruption in Nigeria mostly from the point of view of Nuhu Ribadu. This gives the article some perspective, so readers can have an understanding of what led to the current outrage. Again this history has explained by New York Times clearly depicts Nigeria as a consistently corrupt country. Also some use of colloquial words are evident in the writing, words like 
'Sweet' as used in this sentence, "Cash in the form of sweet crude oil shoots out of the ground in Bayelsa", and 'mere' as used in “...A mere 10 months after his conviction”. These words give the readers a feeling of being in a conversation (informal one) with the writer, rather than reading a serious news article.

\section{Global Superstructure}

The news report is based on the US embassy's criticism of the pardons granted some people convicted of corruption in Nigeria. It uses more of a conversational and narrative format. The article ends abruptly as there is no clear conclusion to the news.

The news answers the $5 \mathrm{Ws}$ and $\mathrm{H}$ of news writing, which are;

'what', 'who' -, 'where'- Nigeria, 'why'-.

What- US criticizes Nigeria

Who - Nigeria

Why - pardon of corrupt people

Where - Nigeria

When- Friday $15^{\text {th }}$ March, 2013

How - through Twitter

\section{Analysis 3: Vanguard Newspaper (Online)}

Headline: Alamieyeseigha has demonstrated enough soberness - Presidency

Writers: Emmanuel Aziken, Henry Umoru, Victor Ahiuma-Young \& Abdulwahab Abdulah

Publication Date: 14th March, 2013

\section{Semantic Macroproposition}

This headline is given in form of a statement attributed to the president of Nigeria. The headline gives us a general idea of the news item is about. From the headline, the readers immediately understand that this news report shall be written from the point of view of the president and other presidential aides. The headline also lets the reader know that this is a burning issue in the country, the choice of using a statement from the presidency is sure to elicit response and some notice to the news item and show that its serious. The headline on its own does not summarise the whole message, but it gives us a general idea of the message and theme of the message. From the headline, we can deduce that the theme of this report is simply a defence of the presidential pardon granted Alamieyeseigha by the presidency. The 
headline also introduces the major players or characters in the news; Alamieyeseigha and the presidency; the presidency includes the president and all other government representatives.

From the headline, one can sense a form of detachment on the part of the writer, the newspaper is careful to make it clear that the statement is not their sentiment or their opinion; rather it is solely representative of what the president said.

\section{Local Meaning}

The participants in this news item are; President Goodluck Jonathan, Alamieyeseigha, Mr. Okupe, Femi Falana, Anwal Ibrahim Musa, and Nigeria Labour Congress (NLC. These participants all play a role in giving weight and authenticity to the report. They give a balanced view of the issue in the news and grant the readers an opportunity to view the news from multiple perspectives. The article is clearly about the presidential pardon of Alamieyeseigha, as shown by the headline and the lead paragraph of the report. The report starts off with a statement from parties, those in support and those against the pardon.

"The Presidency, Thursday, declared that the stabilising role the former Governor of Bayelsa State, Diepreye Alamieyeseigha played to ensure that oil in the Niger Delta was not cut off earned him the state pardon even as the Nigerian Labour Congress and civil society groups insist that the state pardon granted Alamieyeseigha was unacceptable."

This statement sets the mood for readers, you re immediately aware that this piece shall be about arguments and counter-arguments on the presidential pardon. It gives the readers an idea of how the report shall unravel. The article gives a two sided approach to the issue, by presenting arguments from both sides, first from the presidency, then the civil society groups and other stakeholders. However the only people shown to be in support of the pardon are the president and his special adviser on public affairs, Okupe, while there are three major players against the pardon as presented in the report. This might be a ploy to indirectly reflect the papers views on the issue by granting more space to those against the pardon.

The choice creating different sub headings; "pardon is for criminals", FG deceiving Nigerians -Falana", Pardon's a setback -Civil Society", gives the report some form of order and allows the readers organise their thoughts properly. It can also be viewed as an intentional progression of ideas; it starts off with the presidency's point of view and then goes on to 
arguments against the pardon, and ends with the statement that the pardon is a setback. The news might be indirectly conditioning the readers to reject the pardon as unreasonable and uncalled for. Since the arguments presented in the newspaper against the pardon far outweighs those in support of the pardon. Although both parties made very convincing and compelling arguments in support of their views, but the arguments of the presidency is not as potent, because there are no public backings. All statements in support of the pardon were made by government officials. The mind-set of Nigerians is that anything the government says should be taken with a pinch of salt.

Also graphic codes need to be considered when analysing a news text. The picture in this story shows Okupe (Special Adviser to the president on Public Affairs) with the caption 'Mind my roar'. This is an unusual caption for a mainstream newspaper, and it immediately makes one wonder what the motive or the message is exactly. From a previous news report on Okupe where the exact same term was used, it is then clear that the writer views Okupe as a fearless man that speaks his mind no matter whose ox is gored. In this instance, it implies that Okupe would speak his mind whether or not the public supports his sentiments or not.

On the other side of the spectrum, those against the pardon are more diverse, the article as opinions from individuals, civil rights group and organised labour groups. This gives their argument more substance, since the readers would be most likely be able to associate with at least one of the views against the pardon. Apart from the diversity of the arguments against the pardon, this section is also divided using subheadings that gives the readers a quick summary of what the argument is about. The subheadings are short, precise and catchy and have the potential of grabbing readers' attention. This is an advantage the other group (those in support of the pardon) did not have.

The writers were however careful not to make their opinions override the article, as care has been taken to make the whole article words from third parties. This way the authors cannot be blamed for not being objective, as all they have done is simply reporting what different stakeholders had to say on the issue. This is an understandable approach, considering the fact that Nigeria is a country where newspaper houses can be victimised unnecessarily if there are seen to be blatantly against the government in power. 


\section{Global Superstructure}

The news article does not follow a typical news format. It does not make use of the inverted pyramid style, rather it makes use of a debate format, where the opinions of those in favour of the pardon are initially presented, and then counter arguments are subsequently presented. In fact, there is absolutely no plan to answer the $5 \mathrm{~W}$ sand $\mathrm{H}$ in any coherent style, the writers just simply put out different opinions. Though if looked at critically, one might be able to deduce what and who the story is about, where it happened and why. This news report does not give the reader any background on Alameyeiseigha and the corruption case, so for people reading for the first time, it might be difficult to grasp what the story or ruckus is about.

\section{Analysis 4: The Punch Newspaper (Online)}

Headline: Jonathan's 2015 plan behind ex-gov's pardon - Investigation

Writers: Niyi Odebode, John Alechenu, Olusola Fabiyi and Olalekan Adetayo

Publication Date: 14th March, 2013

\section{Semantic Macroproposition}

This headline gives a statement of fact, and according to the writers, this statement is based on investigation. The headline leaves no room for doubt in the fact that the presidential pardon of Alamieyesiegha is a political move to help further President's Jonathan's 2015 ambitions. The headline gives us an idea of what to expect in the body of the news article, but still leaves room for some suspense as the readers would still want to know how the pardon would help further Jonathan's 2015 bid. From the headline, we can deduce the theme of the article. It is clear that this article would be based on exposing the 'hidden agenda' behind the presidential pardon. The headline is catchy and is sure to grab readers' attention, which is what a good headline should achieve. The writers are also clearly challenging the readers and the government to deny the allegations; this is made known by the fact that they used 'investigation'. When people see that a fraud was discovered or a fact unravelled based on investigation, there is an air of authority and authenticity to such a statement. This is what the writers are banking on; assuming that because they have stated that their accusation against the President is based on investigation (fact), then nobody would really be able to accuse them of defamation, slander or biased journalism. 


\section{Local Meaning}

The participants in this news item are; President Goodluck Jonathan, Alamieyeseigha, Mr. Okupe, Mr. Bolaji Adebiyi, Nuhu Ribadu, and Alhaji Mohammed Bulama,. Ribadu, Okupe and Bolaji adebiyi all aired their views on the matter and were given ample opportunity and space to air their opinion. The article started off as claiming this is an investigative piece, but at first reading, it looks like a very shoddy job of investigative journalism and more like reporting hearsays and rumours as fact. The writers did not name any of their sources, neither did they give us any clue as to how they got to get the information they purport to have gotten through investigation.

The first paragraph which is the lead summarises the whole story by given us all the basic elements of the story. From the lead we know 'what' is responsible for the presidential pardon, we know 'why' he was pardoned, we also 'who' was pardoned and 'how' he was pardoned. That use of the word 'fact' in the very first paragraph of the news article is misleading, because it gives the reader the impression that they are going to read some original writing, rather what we see, is what has been written over and over again in other newspapers. As I earlier stated the writers wants the readers to believe that this is an investigative piece and not just simple reporting of the news, as can be seen in the second paragraph where they wrote;

"Investigations showed that President Goodluck Jonathan had recently come under pressure by ex-militants, who have increasingly become critical of his style of leadership".

From the statement above, the writers make certain 'factual' statements, which are not backed up by verifiable sources and authorities. This may be viewed as a ploy to passively influence the perception of the readers into believing that what they are reading is factual. In fact the first 5 paragraphs after the lead paragraph are full of postulations as no particular source is verifiable. After the $6^{\text {th }}$ paragraph, the piece quickly becomes a for-and-against argument, with different quotes from different people. It starts with the Mr. Bolaji Adebiyi stating that "The idea of a presidential pardon was not novel; it is not happening for the first time; it is not peculiar to Nigeria and there is a process. People apply for pardon; they apply to the President who considers it and he follows the process". Then a counter argument is presented from the point of view of Nuhu Ribadu, the former chairman of the Economic and Financial Crimes Commission, and he argued that, "I believe that corruption still remains the 
biggest problem confronting Nigeria. We should not do anything that will take us back. The action by government is capable of stopping the entire war against corruption." This is the format that the article uses till the end. Generally the writers give a holistic view of the arguments given equal opportunities for both parties to air their views, hence giving the readers the freedom to make their own conclusions at least to a large extent.

This article like the other articles reviewed, gives a two sided approach to the issue, by presenting arguments from both sides, but also presents arguments in support of the pardon from only government officials which as the tendency to cast doubt on the motives of those speaking since they represent the same government the publics are criticizing. While on the other hand those against the pardon are represented by a more diverse group which lends their opinion more validity and authenticity. Generally this article looks and feels like the opinion of the writers and then they just looked for quotes to back up their opinion, it is void of relevant sources to back up their investigative claim and it seems rushed.

\section{Global Superstructure}

The news article uses a more traditional writing style. The article has a lead which gives a summary of the key points in the article, the body which basically covers different arguments for and against the subsidy removal, but there is no proper conclusion. The writers give a brief background on presidential pardons in Nigeria. Like the previous article there is really no coherent attempt to apply the $5 \mathrm{Ws}$ and $\mathrm{H}$ of news writing.

\section{Differences and Similarities between the Western and Local Media Depiction of the Presidential Pardon}

The western news media macropropositions are clearer and addresses the issues directly. From their headlines, there is a tendency for the writer's opinions to be reflected. The BBC news for instance made use of "Nigeria Pardons Goodluck Jonathan's Ally". One can notice the writer's sentiment in this statement. The local media on the other hand try not to make their sentiments or opinions reflect on their headlines. They prefer making use of statements for their headlines that are then attributed to a third party. For instance the Vanguards headline reads like this "Alamieyeseigha has demonstrated enough soberness - Presidency" while the Punch headline is also a statement, “Jonathan's 2015 plan behind ex-gov's pardon - 
Investigation". This way the statements/headline cannot be said to reflect the view or opinion of the media houses.

Also the western news media have the tendency of using catchy headlines that van stir up debates. For instance the $\mathrm{BBC}$ headline, indirectly is telling people that Alamieyesegha is a friend to the current president. This insinuation has the tendency to stir up debate. Also the New York Times headline also has the tendency to raise questions. The local media prefer the use of headlines backed up by authority. This provides legitimacy to their headlines. Their headlines are usually attributed to a higher authority. So it is also catchy, but not over sensationalized as compared to the western media. The western media clearly lets the theme of the message known in the headlines and in most cases also tells us the, who, what and why of the message. This is not the case in local media, as they make use of vague statements that has the potential of piquing one's attention, but not enough to understand what the news is about without reading the body of the message. The western news makes use of the more traditional style of writing, with a lead, body and conclusion. They also tend to answer the $5 \mathrm{Ws}$ and $\mathrm{H}$ of news writing as reflected in their writing. They make use of the inverted pyramid style in their structure. Unlike the western media, the local media news coverage of the pardon case usually does not have a clear conclusion. They make use of the narrative and conversational style of writing. The local news do not also make use of the inverted pyramid style, instead they bring in the main points as the story progresses.

\section{Conclusion}

From the foregoing, it is clear that the media is an important tool in promoting an ideology and attributes of a community. How the public views an issue, person or a nation can be linked to the information he or she has about the same issue, person or nation. And since the press (print or electronic) are major sources of information, it is pertinent that care is taken to ensure that all news reports are objective and fair, so as not to influence readers' perception or opinions. From this work we found out that some differences in macropropositions and local meanings between local and western media depictions of the presidential pardon of the ex-governor of Bayelsa state in Nigeria. It can be concluded that a lot of statements and words reflects the writer's bias and opinions and as such might influence the readers' opinions and perception. Whether or not press attempt to influence its publics' opinions and perceptions on certain issues might be beneficial is a fertile ground for further research. 


\section{References}

Africa, B. N. (2013, march 13). Nigeria pardons Goodluck Jonathan ally, Alamieyeseigha. United Kingdom: http://www.bbc.co.uk/news/world-africa-21769047.

Alexa.com. (2013). Top Sites in Nigeria. Retrieved March 20, 2013, from www.alexa.com: www.alexa.com/topsites/countries/NG

Aziken, A., Umoru, H., Ahiuma-Y oung, V., \& Abdulah, A. (2013, March 14). Alamieyeseigha has demonstrated enough soberness - Presidency. Retrieved May 13, 2013, from www.vanguardngr.com: www.vanguardngr.com/2013/03/why-fgpardoned-alamieyeseigha-presidency/

Aziken, E. (2012, October 15). Okupe's roar: Whose war? Retrieved May 13, 2013, from http://www.vanguardngr.com/: http://www.vanguardngr.com/2012/10/okupes-roarwhose-war/

Aziken, E. (2013, march 14). Alamieyeseigha has demonstrated enough soberness Presidency. Abuja, Nigeria: Vanguard Newspaper.

BBC News: Africa. (2013, March 13). Nigeria pardons Goodluck Jonathan ally, Alamieyeseigha. Retrieved April 15, 2013, from www.bbc.co.uk: www.bbc.co.uk/news/world-africa-21769047

Board, E. (2013, March 17). Jonathan's unforgivable State pardon. Lagos, Nigeria: Punch Newspaper.

Fiske, J. (2002). Introduction to Communication Studies. London: Routledge.

Fowler, \& Roger. (1991). language in the News: Discourse and Ideology in the Press. New York: Routledge.

Ghayda, A. (2011). Hero or Terrorist? A Comparative Analysis of Arabic and Western Media Depictions of the Execution of Saddam. Discourse and Communication, 302-335.

Jergenson, M., \& Phillips, L. (2002). Discourse Analysis as Theory and Method. london: Sage Publications.

Nossiter, A. (2013, March 15). US Embassy Critizes Pardons in Nigerian corruption Cases. New York Times.

NOSSITER, A. (2013, March 15). U.S. Embassy Criticizes Pardons in Nigerian Corruption. Retrieved April 15, 2013, from www.nytimes.com: www.nytimes.com/2013/03/16/world/africa/us-embassy-criticizes-pardons-in-nigeriacorruption-cases.html?_r=0 
Odebode, N., Alechenu, J., Fabiyi, O., \& Adetayo, O. (2013, March 14). Jonathan's 2015 plan behind ex-gov's pardon - Investigation. Retrieved April 15, 2013, from www.punchng.com: www.punchng.com/news/jonathans-2015-plan-behind-ex-govspardon-investigation/

Oketola, D., \& Adetayo, o. (2012, December 6). Nigeria is 35th Most Corrupt Nation. Retrieved April 17, 2013, from www.punchng.com: www.punchng.com/news/nigeriais-35th-most-corrupt-nation-ti

Philo, G. (2007). Can Discourse Analysis Successfully Explain The content of Media and Journalistic Practice? Journalism Studies, 175-195.

Van Dijk, T. (1980). Macrostructures: An interdisciplinary Study of Global Structures in Discourse, Interaction and Cognition. New Jersey: Lawrence Erlbaum Associates. Van Dijk, T. (1988). News Analysis: Case Studies of International and National News in the press. New Jersey: Lawrence Erlbaum Associates.

Van Dijk, T. (2005). Semantic Macro-Structures and Knowledge Frames in Discourse Comprehension. www.discourses.org.

Van Dijk, T. (2008). Semantic Discourse Analysis. www.Discourses.org.

Van Djik, T. (2006). Pragmatic Macro-Structures in Discourse and Cognition. www.discourses.org. 